\title{
An analysis of firearms-related deaths between 1993-2010: a retrospective study
}

\author{
Mehmet Toygar, M.D., ${ }^{1}$ Türker Türker, M.D., ${ }^{2}$ Murat Eroğlu, M.D., ${ }^{3}$ Ümit Kaldırım, M.D., ${ }^{4}$ \\ Yavuz Poyrazoğlu, M.D., ${ }^{5}$ Yusuf Emrah Eyi, M.D., ${ }^{6}$ Murat Durusu, M.D., ${ }^{4}$ Mehmet Eryılmaz, M.D. ${ }^{4}$ \\ ${ }^{1}$ Department of Forensic Medicine, GMMA School of Medicine, Ankara \\ ${ }^{2}$ Department of Public Health, GMMA School of Medicine, Ankara \\ ${ }^{3}$ Department of Emergency Medicine, GMMA Haydarpaşa Training Hospital, İstanbul \\ ${ }^{4}$ Department of Emergency Medicine, GMMA School of Medicine, Ankara \\ ${ }^{5}$ Department of General Surgery, Mevki Military Hospital, Ankara \\ ${ }^{6}$ Department of Emergency Medicine, Hakkari Military Hospital, Hakkari
}

\section{ABSTRACT}

BACKGROUND: Firearm injuries (FI) are the most common cause of death among military personnel. In this study, postmortem examination and autopsy records of deaths resulting from firearm injuries recorded in the Department of Forensic Medicine of Gulhane Military Medical Academy between 1993-2010 were examined retrospectively.

METHODS: We evaluated the characteristics of 153 firearm deaths accounting for $36.6 \%$ of all medical-legal autopsies. The cases included I 52 men (99.3\%) and I woman (0.7\%).

RESULTS: The mean age of the cases was 23.1 years ( \pm 4.7 ; range, $20-43$ years). The manner of death was determined in all cases with $41.8 \%$ of cases identified as suicide and $39.9 \%$ as homicide. The most common sites of firearm entrance wounds were the head and neck region $(n=109,71.2 \%)$, the chest $(n=26,17 \%)$, or the abdomen $(n=14,9.2 \%)$. The type of firearm was not clear in most cases.

CONCLUSION: In conclusion, complete forensic and medical records will facilitate the rapid and accurate conclusion of the legal process and will enhance future retrospective studies.

Key words: Firearm deaths; homicide; suicide.

\section{INTRODUCTION}

Firearm injury $(\mathrm{Fl})$ is one of the most important causes of death among military personnel. ${ }^{[1]}$ According to the World Health Organization, firearms are used in two thirds of all homicide cases and one fifth of suicide cases. ${ }^{[2]}$ According to data from the World Health Organization (WHO), 2.3 million people have died as a result of violence worldwide and $26 \%$ of these deaths were war-related deaths. Interpersonal violence, self-mutilation and injuries as a result of war are the

\begin{tabular}{|c|c|}
\hline \multicolumn{2}{|c|}{ Address for correspondence: Mehmet Toygar, M.D. } \\
\hline \multicolumn{2}{|c|}{ Gülhane Askeri Tıp Akademisi, Adli Tıp Anabilim Dalı, Ankara, Turkey } \\
\hline \multicolumn{2}{|l|}{ Tel: $+90312-3044864$} \\
\hline \multicolumn{2}{|c|}{ E-mail: mehmetoygar@yahoo.com } \\
\hline Qucik Response Code & Ulus Travma Acil Cerr Derg \\
\hline 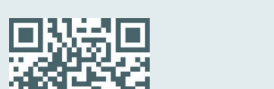 & $\begin{array}{l}20 \mid 3 ; 19(6): 536-542 \\
\text { doi: } 10.5505 / \text { tjtes.20।3.70I } 20\end{array}$ \\
\hline 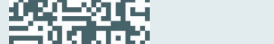 & Copyright 2013 \\
\hline 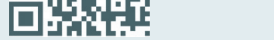 & TJTES \\
\hline
\end{tabular}

most common causes of death in the 15-44 year age population all over the world. ${ }^{[2]}$

In the USA, there are 30,000 firearm-related deaths every year. $^{[3]}$ In a study in Italy, while $27.7 \%$ of forensic autopsies were of deaths resulting from firearm injuries, ${ }^{[4]}$ in India it has been reported that only $1.5 \%$ of forensic autopsies are of deaths resulting from firearm injuries. ${ }^{[5]}$

In Turkey according to the data of National Statistical Institute (TurkStat), firearm injuries are the most common cause of homicides and the third cause of suicides following poisoning and hanging. ${ }^{[6,7]}$ According to the 2008 data of TurkStat, $0.3 \%(749 / 215.562)$ of deaths were caused by firearms apart from deaths in warfare. ${ }^{[6]}$ In our country, studies evaluating forensic cases have stated mortality rates of $8.2-27.7 \%$ from firearms injuries. ${ }^{[8-12]}$

This study aimed to analyze the demographic data of cases of firearms injury which underwent an autopsy in our department and to compare that data with other studies. 


\section{MATERIALS AND METHODS}

A retrospective examination was made of postmortem examination and autopsy records in the Department of Forensic Medicine of Gulhane Military Medical Academy of deaths resulting from firearms injuries between 1993-2010. Approval for the study was granted by the Local Ethics Committee. It was determined that examination and autopsy were conducted on a total of 417 forensic qualified cases. The records were examined of 153 (36.6\%) of these deaths, which were firearms related. Explosive substance-related deaths were not included in the study. Cases were evaluated according to the autopsy records, age, gender, manner of death, site of entrance wound, exit wound location, length of stay in hospital, range of fire, type of firearm, whether bullets were obtained from the corpse or not, the number of bullets that hit the body and toxicological examinations.

\section{RESULTS}

\section{Demographic Characteristics}

In this study, examination and autopsy processes were conducted on 417 forensic qualified cases including 153 firearmsrelated death cases. These cases were 152 male (99.3\%) and I female $(0.7 \%)$ with a mean age of $23.1 \pm 4.7$ years (range, 20-43 years).

\section{Manner of Death}

Cases were examined according to the manner of death and it was determined that $41.8 \%$ of the cases were suicide, $39.9 \%$ were homicide, $9.2 \%$ were accident and $9.2 \%$ were from other causes (non-specific origin in the medical and investigative documents).

\section{Types of Firearms}

The type of firearm used was not clear in $59.5 \%$ of all cases. It was interesting that the type of firearm could not be determined in all the cases in which the manner of death could not be determined (Table I).

\section{Wound Characteristics}

The distribution of firearm entry wounds were evaluated according to the body parts; entry wound was in head and neck region of $109(71.2 \%)$ of victims, in chest of 26 (17\%), in abdomen of $14(9.2 \%)$ and in lower extremity of $4(2.6 \%)$. In the cases with multiple-entry wound, the vital localizations of entry wounds were considered.

When the distribution of firearm exit wound of cases was evaluated according to the body parts. The exit wound was in the head and neck region of $96(62.7 \%)$ cases, in the back of $30(19.6 \%)$, in the abdomen of $8(5.2 \%)$ and in the lower extremity of 4 (2.6\%). It was also detected that 9 cases had no exit wound and in 6 cases the exit wound could not be defined because of atypical wound characteristics. In the cases with multiple-exit wounds, the vital localization of the exit wounds was considered.

Table I. The type of firearm used according to the manner of death

\begin{tabular}{|c|c|c|c|c|c|c|c|c|c|c|}
\hline \multirow[t]{2}{*}{ Types of firearms } & \multicolumn{2}{|c|}{ Homicide } & \multicolumn{2}{|c|}{ Suicide } & \multicolumn{2}{|c|}{ Accident } & \multicolumn{2}{|c|}{ Not-Specified } & \multicolumn{2}{|c|}{ Total } \\
\hline & $\mathbf{n}$ & $\%$ & $\mathbf{n}$ & $\%$ & $\mathbf{n}$ & $\%$ & $\mathbf{n}$ & $\%$ & $\mathbf{n}$ & $\%$ \\
\hline Long-barrelled & 10 & 16.4 & 34 & 53.1 & 2 & 14.3 & 0 & 0 & 46 & 30.1 \\
\hline Short-barrelled & 4 & 6.6 & 7 & 10.9 & 5 & 35.7 & 0 & 0 & 16 & 10.4 \\
\hline Not-Specified & 47 & 77 & 23 & 35.9 & 7 & 50 & 14 & 100 & 91 & 59.5 \\
\hline \multirow[t]{2}{*}{ Total } & 61 & 100 & 64 & 100 & 14 & 100 & 14 & 100 & 153 & 100 \\
\hline & 39.9 & & 41.8 & & 9.2 & & 9.2 & & 100 & \\
\hline
\end{tabular}

Table 2. Entry wound localization according to the manner of death

\begin{tabular}{|c|c|c|c|c|c|c|c|c|c|c|}
\hline \multirow[t]{2}{*}{ Entry area } & \multicolumn{2}{|c|}{ Homicide } & \multicolumn{2}{|c|}{ Suicide } & \multicolumn{2}{|c|}{ Accident } & \multicolumn{2}{|c|}{ Not-Specified } & \multicolumn{2}{|c|}{ Total } \\
\hline & $\mathbf{n}$ & $\%$ & $\mathbf{n}$ & $\%$ & $\mathbf{n}$ & $\%$ & $\mathbf{n}$ & $\%$ & $\mathbf{n}$ & $\%$ \\
\hline Head-neck & 44 & 72.1 & 45 & 70.3 & 9 & 64.3 & II & 78.6 & 109 & 71.2 \\
\hline Chest & 10 & 16.4 & 11 & 17.2 & 3 & 21.4 & 2 & 14.3 & 26 & 17 \\
\hline Abdomen & 5 & 8.2 & 8 & 12.5 & 1 & 7.1 & 0 & 0 & 14 & 9.2 \\
\hline Lower extremity & 2 & 3.3 & 0 & 0 & 1 & 7.1 & 1 & 7.1 & 4 & 2.6 \\
\hline \multirow[t]{2}{*}{ Total } & 61 & 100 & 64 & 100 & 14 & 100 & 14 & 100 & 153 & 100 \\
\hline & \multicolumn{2}{|c|}{39.9} & \multicolumn{2}{|c|}{41.8} & \multicolumn{2}{|c|}{9.2} & \multicolumn{2}{|c|}{9.2} & \multicolumn{2}{|c|}{100} \\
\hline
\end{tabular}


When the entry wound localization was examined according to the manner of death, the head and neck was the most frequent site of wounding regardless of the manner of death (Table 2).

\section{Range of Fire}

When the cases were evaluated according to the range of fire, while it was not clear in $43.1 \%$ of cases, there was, a contact/ near contact shot in $44.4 \%$, a close shot in $4.6 \%$ and a distant shot in $7.8 \%$. In the autopsy reports, the range of fire could not be defined in $43.1 \%$ of all cases and in $78.6 \%$ of accidental cases. This was because the shot was made to a clothed area or there had been medical intervention to the entry wound(s) (the identification of the features of the entry wounds were not made in the medical records before medical intervention, and the information about analysis results in terms of range of fire of perforated clothing was not found from the available data of shots made to a clothed area) (Table 3).
In the analysis of the type of weapon according to the range of fire, it was observed that cases in which the type of the weapon could not be determined, mostly consisted of cases in which the range of fire could not be determined (Table 3). When the range of fire was examined according to the manner of death of cases, it was striking that the range of fire could not be determined in most of the accidental firearm deaths (Table 4).

\section{The Entry Wound Localization According to the Range of Fire}

When the entry wound localization of cases was examined according to the range of fire, the entry wound was in the head area in $62.4 \%$ of the cases with an undetermined shot (Table 5).

It is interesting that cases with gunshot wounds in the chest and abdomen were not wounded with short-barrelled guns.

Table 3. The range of fire according to the type of firearm

\begin{tabular}{|c|c|c|c|c|c|c|c|c|}
\hline \multirow[t]{2}{*}{ Range of fire } & \multicolumn{2}{|c|}{ Long barrelled } & \multicolumn{2}{|c|}{ Short barrelled } & \multicolumn{2}{|c|}{ Not-specified } & \multicolumn{2}{|c|}{ Total } \\
\hline & $\mathbf{n}$ & $\%$ & $\mathbf{n}$ & $\%$ & $\mathbf{n}$ & $\%$ & $\mathbf{n}$ & $\%$ \\
\hline Contact/near contact & 26 & 38.2 & 8 & 11.8 & 34 & 50 & 68 & 44.4 \\
\hline Close & 2 & 28.6 & 0 & 1.6 & 5 & 71.4 & 7 & 4.6 \\
\hline Distant & 4 & 33.3 & 1 & 8.3 & 7 & 58.4 & 12 & 7.8 \\
\hline Undetermined & 14 & 21.2 & 7 & 10.6 & 45 & 68.2 & 66 & 43.1 \\
\hline Total & 46 & 30.1 & 16 & 10.4 & 91 & 59.5 & 153 & 100 \\
\hline
\end{tabular}

Table 4. The range of fire according to the manner of death

\begin{tabular}{|c|c|c|c|c|c|c|c|c|c|c|}
\hline \multirow[t]{2}{*}{ Range of fire } & \multicolumn{2}{|c|}{ Homicide } & \multicolumn{2}{|c|}{ Suicide } & \multicolumn{2}{|c|}{ Accident } & \multicolumn{2}{|c|}{ Not-Specified } & \multicolumn{2}{|c|}{ Total } \\
\hline & $\mathbf{n}$ & $\%$ & $\mathbf{n}$ & $\%$ & $\mathbf{n}$ & $\%$ & $\mathbf{n}$ & $\%$ & $\mathbf{n}$ & $\%$ \\
\hline Contact/near contact & 18 & 29.5 & 42 & 65.6 & 2 & 14.3 & 6 & 42.9 & 68 & 44.4 \\
\hline Close & 3 & 4.9 & 1 & 1.6 & 1 & 7.1 & 2 & 14.3 & 7 & 4.6 \\
\hline Distant & 12 & 19.7 & 0 & 0 & 0 & 0 & 0 & 0 & 12 & 7.8 \\
\hline Undetermined & 28 & 45.9 & 21 & 32.8 & 11 & 78.6 & 6 & 42.9 & 66 & 43.1 \\
\hline Total & 61 & 100 & 64 & 100 & 14 & 100 & 14 & 100 & 153 & 100 \\
\hline
\end{tabular}

Table 5. The entry wound localization according to the type of firearm

\begin{tabular}{|c|c|c|c|c|c|c|c|c|}
\hline \multirow[t]{2}{*}{ Range of fire } & \multicolumn{2}{|c|}{ Long barrelled } & \multicolumn{2}{|c|}{ Short barrelled } & \multicolumn{2}{|c|}{ Not-specified } & \multicolumn{2}{|c|}{ Total } \\
\hline & $\mathbf{n}$ & $\%$ & $n$ & $\%$ & $\mathbf{n}$ & $\%$ & $n$ & $\%$ \\
\hline Head-neck & 26 & 23.8 & 15 & 13.8 & 68 & 62.4 & 109 & 71.2 \\
\hline Chest & 13 & 50.0 & 0 & - & 13 & 50.0 & 26 & 17.0 \\
\hline Abdomen & 6 & 42.9 & 0 & - & 8 & 67.1 & 14 & 9.2 \\
\hline Lower extremity & I & 25.0 & 1 & 25.0 & 2 & 50.0 & 4 & 2.6 \\
\hline Total & 46 & & 16 & & 91 & & 153 & 100 \\
\hline
\end{tabular}




\section{Toxicological Review}

In the autopsy reports of firearm-related deaths, no toxic substance was determined in $55.6 \%$ of materials and xycain, ethyl alcohol, prilocaine, lidocaine, barbiturates, benzodiazepines and atropine were found in $3.9 \%$. No toxicological review was applied to $39.9 \%$ of cases because of lengthy hospitalization and medical treatment.

\section{Bullets}

When the cases were evaluated according to the number of bullets that hit the body, it was determined that $86.9 \%$ died with one bullet injury, $7.2 \%$ with two bullet injuries and $5.9 \%$ with three or more bullet injuries.

Bullets were not retrieved in the autopsy of $94.8 \%$ of cases who died as a result of firearms injury, and were rerieved from $5.2 \%$ of cases and were handed over to the judicial authorities.

\section{Death from Complications}

$61.4 \%$ of the cases died at the crime scene, during transport on the road or in the emergency services. In $55.3 \%$ of cases, the weapon type could not be ascertained, $35.1 \%$ were shot with a long-barrelled weapon and $9.6 \%$ with a short-barrelled weapon.

Analysis of the cases who died at the crime scene, during transport on the road or in the emergency services determined the following data; $68.1 \%$ were injured in the head area, $21.3 \%$ in the chest and $9.6 \%$ in the abdomen; $63.8 \%$ were shot from a contact/near contact shot, $6.4 \%$ from a close shot, $10.6 \%$ from a distant shot and the range of fire could not be determined in $19.1 \%$ of these cases; the origin was homicide in $36.2 \%$, suicide in $46.8 \%$ and no clear origin was determined in $10.6 \%$.

In this study, the duration of hospitalization and medical treatment ranged from I day to 630 days. Hospitalization was less than 90 days in $96.1 \%$ of cases.

\section{DISCUSSION}

In this study covering a period of 17 years between 1993$2010,153(36.6 \%)$ of the 417 forensic qualified cases that underwent examination and autopsy procedures originated from firearms. Previous studies in our country have reported this rate as between $7.4 \%-27.7 \% .^{[8-12]}$ In a study by Norton and Langley in New Zealand, this rate was $0.3 \%$, ${ }^{[13]}$ Nizamo et $\mathrm{al}^{\left[{ }^{[14]}\right.}$ reported this rate as $8.7 \%$ in Mozambique, and Biago Solarino ${ }^{[4]}$ determined this rate to be $27.7 \%$ in Italy. In the current study, this ratio is higher because the population served by our health center has access to firearms.

Studies evaluating deaths from firearms injuries have shown that these deaths especially concern the 20-40 year group. ${ }^{[9-}$ 12] Parallel to literature, the cases in the current study ranged from 20-43 years of age. In a study by Azmak et al in Edirne, the cases were primarily in the $2 \mathrm{l}-30$ years age group, followed by the $3 \mathrm{I}-40$ years age group. ${ }^{[8]}$ In other studies in Iran (38.2\%), ${ }^{[15]}$ in Africa ${ }^{[16]}$ and in India (46.7\%) in a study by Kohli et $\mathrm{al}^{[5]}$ it has been stated that cases were most common in the 20-30 years age group. Other studies in other regions such as Sweden, Germany, the United States and South Africa have also yielded similar results. ${ }^{[5,15-21]}$

A contact/near contact shot is the range of fire in the majority of suicide cases, ${ }^{[8,22-25]}$ while a close or distant shot has been the range of fire determined in the majority of homicide cases. ${ }^{[23,26]}$ Druid identified that firearm wounds in homicides were made from a contact/near contact shot or a close shot and in $99 \%$ of suicide cases it was a close shot. ${ }^{[27]}$ In a study by Azmak et al it was determined that the range of fire was mostly a distant shot, was not detected in $8 \%$ of cases, and was a contact shot in almost all suicide cases. ${ }^{[8]}$ The range of fire could not be determined in $32.8 \%$ of suicide cases, because the shot had been made to a clothed area or there had been medical intervention to the entry wound. Definition of the entry wound features had not been entered in the medical records before medical intervention, so there was insufficient information in terms of range of fire in the data obtained from the analysis results of perforated clothing in a shot made to a clothed area. It is estimated that the majority of these cases were from a distant shot.

When the cases of the current study were evaluated according to origin, it was determined that $39.9 \%$ were homicide. Although several studies have stated this rate as ranging between $62.2 \%-71.80 \%$, it was determined by Solarino et al ${ }^{[4]}$ as $88.4 \%$, by Kellermann ${ }^{[28]}$ as $88 \%$, by Guileyardo ${ }^{[29]}$ as $65 \%$, by Riddick ${ }^{[30]}$ as $53 \%$, by Al Ragheb ${ }^{[31]}$ as $51 \%$, by Verzeletti et $\mathrm{a}^{[32]}$ as $35.9 \%$, and by Druid ${ }^{[27]}$ as $18.7 \%$. While the results of the current study are similar to those of some previous studies, they are also different from those of some others.

In the current study, 4I.8\% were suicide cases. In several studies in our country this rate has been reported as between $11.70-32.7 \%^{[6,8,33-35]}$ and in studies in other countries as $6.5-73.9 \% .^{[5,27,32]}$ Researchers have reported a strong relationship between access to firearms and suicide. ${ }^{[36-38]}$ In the current study, the suicide rate is higher than in other studies, which may be due to a high rate of accessibility to firearms of the study population.

In the current study, 9.2\% were accidental cases. This rate has been reported as ranging between $0.13-24 \%$ in previous studies. $^{[4-6,8,11,33-35]}$ Copeland and Ornehult made a detailed study of accidental firearms deaths together with crime scene investigation and it was reported that the firearms accidents could have occured as a result of playing with firearms, showing the weapon others or because of faulty firearms. ${ }^{[39,40]}$ These features are similar to the findings of accidental deaths in the current study. 
In studies by Azmak, ${ }^{[8]}$ Al Ragheb, ${ }^{[31]}$ Riddick, ${ }^{[30]}$ Muscat, ${ }^{[4]}$ Verzeletti[ ${ }^{[32]}$ and Solarino ${ }^{[4]}$ short barrelled weapon types were determined to have been used in homicide cases. In contrast, Druid stated that the weapon type most used in homicide cases was a shotgun and secondly, rifles. However, attention was also drawn to the fact that in $44 \%$ of homicide cases information about the weapon type could not be obtained. ${ }^{[27]}$ In the current study, in most of the homicide cases (77\%), the type of firearm could not be determined because information about the weapon type was not available (terrorism, medical intervention to patients in more than one place, attempts to firstly rescue the patients rather than assessing the judicial aspect of cases and therefore no record of the type of weapon in judicial records etc.). In the current study, the type of the firearm could not be determined in all cases in which the manner of death could not be determined. This may suggest a strong relationship between these two factors. In a study by Azmak et al, ${ }^{[8]}$ the weapon type used in $50 \%$ of suicide cases was reported to be a handgun. In other studies, similar results have also been reported. ${ }^{4,8,32,38]}$

Al Ragheb, ${ }^{[3 !]}$ Riddick $^{[30]}$ and Muscat ${ }^{[4 !]}$ reported that while the handgun was common in suicide cases in the civil population, rifled weapons were common in military populations. The preferred weapon type in suicide cases of the current study was mostly long barrelled (53.1\%), which is due to a higher rate of use of long barrelled weapons in the study population.

In a study of homicides by Amiri, the most common entry wound site was reported as $42.6 \%$ head, $42.6 \%$ chest and $16.7 \%$ back, ${ }^{[15]}$ which conforms with the results of previous

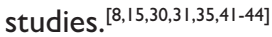

Azmak reported that the entry wound was in the head (right temporal area, left temporal area and neck) in 65\%, in the chest in $25 \%$ and in the abdomen in $10 \%$ of suicide cases. ${ }^{[8]}$ Ağritmiş ${ }^{[6]}$ reported that the most common entry wound localization is in the head-neck, chest and abdomen in children and adolescents. Similar findings have been reported in previous studies. ${ }^{[15,30,31,36,42,47]} \mathrm{Di}$ Maio ${ }^{[47]}$ stated that in suicide cases with handguns and long barrelled weapons, the most common entry wound localization was in the head area, and this result is compatible with the findings of the current study.

The gun type was identified when the entry wound localization was in the head-neck area in all cases of homicide. It can be seen that almost all the findings of the current study conform with the findings of other studies.

Muscat ${ }^{[4]}$ reported that the most commonly seen entry wound localization in homicide with a handgun is the headneck area. In homicide cases where a long-barrelled weapon had been used the most common entry wound localization has been reported as the chest area. ${ }^{[41]}$
Rates of single entry wound have been reported by Feda$\operatorname{kar}^{[35]}$ as $70.9 \%$ of cases, by Amiri ${ }^{[15]}$ as $65.2 \%$, by Verzeletti[ ${ }^{[32]}$ as $74.8 \%$, by $\mathrm{Kohli}^{[5]}$ as $77 \%$, and by $\mathrm{Azmak}^{[8]}$ as $74.1 \%$. When the current study was evaluated according to single entry wound, the findings are consistent with literature.

Azmak, ${ }^{[8]}$ Kohli $^{[5]}$ and Goren ${ }^{[34]}$ reported that the majority of cases that died as a result of firearms injury died at the crime scene, during transportation or in the emergency services. Similar to the findings of other studies, the majority of the cases in the current study died within 24 hours.

Verzeletti ${ }^{[32]}$ detected alcohol, amphetamines, opiates, cannabinoid, and cocaine in $35 \%$ of cases and Şam ${ }^{[6]}$ detected substances such as ethyl alcohol, stimulants, narcotics or psychoactivants in $24 \%$ of cases. Galea ${ }^{[48]}$ identified positive drug results in more than half of cases and the most detected substances $(24.2 \%)$ were cannabis (19.5\%), opiates $(9.6 \%)$, and alcohol (26.9\%). Druid ${ }^{[27]}$ identified an association between alcohol and the majority of murder and suicide cases. Bilban ${ }^{[49]}$ identified alcohol in $68.8 \%$ of suicide cases who died as a result of firearms injury. Bosnar ${ }^{[50]}$ reported significantly high blood alcohol concentrations in suicide cases that occurred with firearms in time of war. Alcohol has been found in $62 \%$ of homicide cases in Sweden ${ }^{[51]}$ and $68.6 \%$ of murder cases in Norway. ${ }^{[52]}$ According to literature, in the current study, substances were identified at very low rates in the toxicological analysis. The reason for this low rate is that the study group was living in an environment which was often checked in respect of substance abuse and where alcohol or other harmful substances were not permitted.

\section{Conclusion}

As our department serves people who have been authorized to use firearms, firearms injuries are a more frequently encountered issue in our department than in other institutions relevant to the subject. However, it can be seen that there is no great difference in terms of demographic data. As the most common injury areas in firearms-related death and injury cases are localized in the head-neck and chest, taking precautions (hard hat, protective clothing etc.) in these areas is thought to decrease the number of injuries and deaths.

The results of this study suggest a strong relationship between criminal findings such as non-identification of the type of firearm and range of fire and the manner of death and clarification of the incident. Attempting to make a medical intervention quite rightly to save life and thus focusing on a therapeutic direction creates problems in keeping detailed and proper records of medical interventions in these type of forensic cases and in the clarification of investigations. This leads to a prolonged legislative process and leaves some questions unanswered that should be answered by the official authorities. We think that keeping complete forensic and medical records will lead to a more rapid and accurate conclusion 
of the legal process and thus future retrospective research will be able to reflect more accurate and objective results.

\section{Conflict of interest: None declared.}

\section{REFERENCES}

1. Powell KE, Fingerhut LA, Branche CM, Perrotta DM. Deaths due to injury in the military. Am J Prev Med 2000;18:26-32. [CrossRef]

2. http://whqlibdoc.who.int/hq/2001/WHO_NMH_VIP_01.1.pdf. Available date: Aug 18, 2012.

3. Denton JS, Segovia A, Filkins JA. Practical pathology of gunshot wounds. Arch Pathol Lab Med 2006;130:1283-9.

4. Solarino B, Nicoletti EM, Di Vella G. Fatal firearm wounds: a retrospective study in Bari (Italy) between 1988 and 2003. Forensic Sci Int 2007;168:95-101. [CrossRef]

5. Kohli A, Aggarwal NK. Firearm fatalities in Delhi, India. Leg Med (Tokyo) 2006;8:264-8. [CrossRef]

6. Şam B, Kaya E.A, Özdemir M, Arpak B.B, Makça C. İstanbul'da 2003 2007 yılları arasında gerçekleşmiş ateşli silah yaralanmasına bağlı ölümler. 1. Uluslararas1 Avrasya Adli Bilimler Kongresi.

7. Turkish Statistical Institute. Death Statistics Province and District Centers 2008.

8. Azmak D, Altun G, Bilgi S, Yilmaz A. Firearm fatalities in Edirne, 19841997. Forensic Sci Int 1998;95:231-9. [CrossRef]

9. Salaçin S. An analysis of the medicolegal autopsies performed in Adana, Turkey, in 1983-1988. Am J Forensic Med Pathol 1991;12:191-3. [CrossRef]

10. Çoltu A, Durak D. A retrospective examination of forensic autopsies of 141 firearm wound cases. J Forensic Med (in Turkish) 1992;8:49-51.

11. Karagöz YM, Karagöz SD, Atilgan M, Demircan C. An analysis of 133 firearm deaths. In: 2nd Congress of Forensic Sciences, Bursa, May 13-16, 1996.

12. Ertürk S, Ege B, Karaali H. Different ways of firearm injuries in forensic medicine. J Forensic Med (in Turkish) 1989;5:27-32.

13. Norton R, Langley J. Firearm related deaths in New Zealand 1978-87. N Z Med J 1993;106:463-5.

14. Nizamo H, Meyrowitsch DW, Zacarias E, Konradsen F. Mortality due to injuries in Maputo City, Mozambique. Int J Inj Contr Saf Promot 2006;13:1-6. [CrossRef]

15. Amiri A, Sanaei-Zadeh H, Towfighi Zavarei H, Rezvani Ardestani F, Savoji N. Firearm fatalities. A preliminary study report from Iran. J Clin Forensic Med 2003;10:159-63. [CrossRef]

16. Meel B. Trends in firearm-related deaths in the Transkei region of South Africa. Am J Forensic Med Pathol 2007;28:86-90. [CrossRef]

17. Meel BL. Firearm fatalities in the Transkei region of South Africa, 1993 2004. S Afr Med J 2005;95:963-7.

18. Karger B, Billeb E, Koops E. Accidental firearm fatalities. Forensic and preventive implications. Int J Legal Med 2002;116:350-3.

19. Onuminya JE, Ohwowhiagbese E. Pattern of civilian gunshot injuries in Irrua, Nigeria. S Afr J Surg 2005;43:170-2.

20. Ikeda RM, Gorwitz R, James SP, Powell KE, Mercy JA. Trends in fatal firearm-related injuries, United States, 1962-1993. Am J Prev Med 1997; 13:396-400.

21. Hardt-Madsen M, Simonsen J. Firearms fatalities in Denmark 19701979. Forensic Sci Int 1983;23:93-8. [CrossRef]

22. Ropohl D, Koberne F. Fatal shotgun use in peace time. [Article in German] Beitr Gerichtl Med 1990;48:339-48. [Abstract]

23. Karger B, Billeb E, Koops E, Brinkmann B. Autopsy features relevant for discrimination between suicidal and homicidal gunshot injuries. Int J Legal Med 2002;116:273-8.

24. Stone IC. Characteristics of firearms and gunshot wounds as markers of suicide. Am J Forensic Med Pathol 1992;13:275-80. [CrossRef]

25. Karlsson T. Multivariate analysis ('forensiometrics')--a new tool in forensic medicine. Differentiation between firearm-related homicides and suicides. Forensic Sci Int 1999;101:131-40. [CrossRef]

26. Thomsen JL, Albrektsen SB. An investigation of the pattern of firearms fatalities before and after the introduction of new legislation in Denmark. Med Sci Law 1991;31:162-6.

27. Druid H. Site of entrance wound and direction of bullet path in firearm fatalities as indicators of homicide versus suicide. Forensic Sci Int 1997;88:147-62. [CrossRef]

28. Kellermann AL, Rivara FP, Lee RK, Banton JG, Cummings P, Hackman BB, et al. Injuries due to firearms in three cities. $\mathrm{N}$ Engl J Med 1996;335:1438-44. [CrossRef]

29. Guileyardo JM, Carmody TJ, Lene WJ, Stone IC. Racial and ethnic patterns in firearms deaths. Am J Forensic Med Pathol 1994;15:328-30.

30. Riddick L, Wanger GP, Fackler ML, Carter RD, Hoff CJ, Jinks JM, et al. Gunshot injuries in Mobile County, Alabama: 1985-1987. Am J Forensic Med Pathol 1993;14:215-25. [CrossRef]

31. Al Ragheb SY. Firearm fatalities in Jordan. Med Sci Law 1984;24:21321.

32. Verzeletti A, Astorri P, De Ferrari F. Firearm-related deaths in Brescia (Northern Italy) between 1994 and 2006: a retrospective study.J Forensic Leg Med 2009;16:325-31. [CrossRef]

33. Günaydın G, Demirci S. Konyáda 1991-2000 yılları arasında atesli silah yaralanması nedeniyle ölen 248 olgunun degerlendirilmesi. Yillık Adli Tip Toplantiları Antalya 2002, 2002. s. 308-13.

34. Goren S, Subasi M, Tirasci Y, Kemaloglu S. Firearm-related mortality: a review of four hundred-forty four deaths in Diyarbakir, Turkey between 1996 and 2001. Tohoku J Exp Med 2003;201:139-45. [CrossRef]

35. Fedakar R, Gündoğmuş UN, Türkmen N. Firearm-related deaths in two industrial cities of Turkey and their province. Leg Med (Tokyo) 2007;9:14-21. [CrossRef]

36. Avis SP. Suicidal gunshot wounds. Forensic Sci Int 1994;67:41-7. [CrossRef]

37. Wiebe DJ. Homicide and suicide risks associated with firearms in the home: a national case-control study. Ann Emerg Med 2003;41:771-82.

38. Boyd JH. The increasing rate of suicide by firearms. N Engl J Med 1983;308:872-4. [CrossRef]

39. Copeland AR. Accidental death by gunshot wound--fact or fiction. Forensic Sci Int 1984;26:25-32. [CrossRef]

40. Ornehult L, Eriksson A. Fatal firearm accidents in Sweden. Forensic Sci Int 1987;34:257-66. [CrossRef]

41. Muscat JE, Huncharek MS. Firearms and adult, domestic homicides. The role of alcohol and the victim. Am J Forensic Med Pathol 1991;12:105-10.

42. Selway R. Gunshot suicides in Victoria, Australia, 1988. Med Sci Law 1991;31:76-80.

43. Selway R. Firearm fatalities in Victoria, Australia 1988. Med Sci Law 1991;31:167-74.

44. Rammelsberg JO, Nowak R. Homicide by gunshot. An evaluation of 50 homicides with reference to gunshot wound site. [Article in German] Arch Kriminol 1999;203:65-72. [Abstract]

45. Betz P, Peschel O, Eisenmenger W. Suicidal gunshot wounds--site and characteristics. [Article in German] Arch Kriminol 1994;193:65-71. [Abstract]

46. Ağritmiş H, Yayci N, Colak B, Aksoy E. Suicidal deaths in childhood and adolescence. Forensic Sci Int 2004;142:25-31. [CrossRef] 
47. Di Maio VJM. Gunshot wounds - practical aspects of firearms, ballistics and forensic techniques. New York: Elsevier; 1985. p. 294-7.

48. Galea S, Ahern J, Tardiff K, Leon AC, Vlahov D. Drugs and firearm deaths in New York City, 1990-1998. J Urban Health 2002;79:70-86.

49. Bilban M, Skibin L. Presence of alcohol in suicide victims. Forensic Sci Int 2005;147:9-12. [CrossRef]

50. Bosnar A, Stemberga V, Coklo M, Koncar GZ, Definis-Gojanovic M,
Sendula-Jengic V, et al. Suicide and the war in Croatia. Forensic Sci Int 2005;147 Suppl:13-6. [CrossRef]

51. Sjögren H, Eriksson A, Broström G, Ahlm K. Quantification of alcoholrelated mortality in Sweden. Alcohol Alcohol 2000;35:601-11. [CrossRef]

52. Nordrum I, Eide TJ, JŁrgensen L. Alcohol in a series of medico-legally autopsied deaths in northern Norway 1973-1992. Forensic Sci Int 2000;110:127-37. [CrossRef]

\title{
KLINIKK ÇALIŞMA - ÖZET
}

\section{3-2010 yılları arasında gerçekleşmiş ateşli silah yaralanmasına bağlı ölümler: Geriye dönük çalı̧̧ma \\ Dr. Mehmet Toygar, ${ }^{1}$ Dr. Türker Türker, ${ }^{2}$ Dr. Murat Eroğlu, ${ }^{3}$ Dr. Ümit Kaldırım, ${ }^{4}$ Dr. Yavuz Poyrazoğlu, ${ }^{5}$ Dr. Yusuf Emrah Eyi, ${ }^{6}$ Dr. Murat Durusu, ${ }^{4}$ Dr. Mehmet Eryılmaz ${ }^{4}$}

\author{
${ }^{1}$ Gülhane Askeri Tıp Akademisi, Adli Tıp Anabilim Dalı, Ankara \\ ${ }^{2}$ Gülhane Askeri Tıp Akademisi, Halk Sağlığı Anabilim Dalı, Ankara \\ ${ }^{3}$ Gülhane Askeri Tıp Akademisi Haydarpaşa Eğitim Hastanesi, Acil Tıp Anabilim Dalı, İstanbul \\ ${ }^{4}$ Gülhane Askeri Tıp Akademisi, Acil Tıp Anabilim Dalı, Ankara \\ ${ }^{5}$ Mevki Asker Hastanesi, Genel Cerrahi Kliniği, Ankara \\ ${ }^{6}$ Hakkari Asker Hastanesi, Acil Tıp Kliniği, Hakkari
}

AMAÇ: Ateşli silah yaralanmaları (ASY) askeri personelin en sık ölüm sebebidir. Bu çalışmada, Gülhane Askeri Tıp Akademisi Adlı Tıp Anabilim Dalı'na I993-2010 yılları arasında ateşli silah yaralanmasına bağlı ölümlere ait postmortem muayene ve otopsi kayıtlarının geriye dönük analizi amaçlandı.

GEREÇ VE YÖNTEM: Olguların I53'ünün (\%36.6) ateşli silah kaynaklı olduğu gözlendi. Olguların \%99.3'ü erkek (n=I52), \%0.7'si kadın idi (n=I). Yaş ortalaması 23. I \pm 4.7 yıl (20-43 yıl) idi.

BULGULAR: Olgular ölüm biçimine göre değerlendirildiğinde \%4I.8'i intihar, \%39.9'u cinayetti. En sık atesli silah giriş bölgesi sırasıyla baş-boyun I09 (\%7I.2), toraks 26 (\%।7) ve abdomen 14 (\%9.2) idi. Olguların çoğunda ateşli silah tipi belli değildi.

TARTIŞMA: Sonuç olarak adli ve tıbbi kayıtların tam ve düzgün tutulmasının yasal sürecin doğru ve hızlı sonuçlanmasına ve ileride yapılacak geriye dönük araştırmalarda daha doğru ve objektif sonuçların yansıtılmasına neden olacağı kanaatindeyiz.

Anahtar sözcükler: Ateşli silah ölümleri; cinayet; intihar.

Ulus Travma Acil Cerr Derg 2013;19(6):536-542 doi: 10.5505/tjtes.2013.70120 